\title{
Management practices in micro and small enterprises: the relationships between practices adopted and funding
}

\author{
Juliana Gonçalves de Araújo* \\ PROPAD/UFPE, \\ Av. dos Reitores s/n - Cidade Universitária, PE, Brazil \\ Email: juhliana.araujo@gmail.com \\ *Corresponding author

\section{Umbelina Cravo Texeira Lagioia and Aldemar de Araújo Santos} \\ UFPE, \\ Av. dos Reitores s/n - Cidade Universitária, PE, Brazil \\ Email: umbelinalagioia@gmail.com \\ Email: aldemar@ufpe.br \\ Rodrigo Vicente dos Prazeres \\ PPGCC/UFPE, \\ Av. dos Reitores s/n - Cidade Universitária, PE, Brazil \\ Email: rodrigovprazeres@gmail.com
}

\begin{abstract}
This paper aims to analyse the relationships between management accounting practices and sources of financing. Data were collected from a survey questioning the profiles, the sources of financing and the management practices adopted by 52 small business in a textile cluster. It could be observed that $38.5 \%$ of the firms were initially fund-raised by family resources and that $42.3 \%$ resorted to the personal funds of the owner. As for resources used to maintain the business, $34 \%$ of the respondents answered that it was obtained from banks and $21.2 \%$ told that it came from their own resources. Through $\mathrm{U}$ Mann-Whitney test, it was found that sources of resources of family origin indicated significant negative associations with management and control practices. A different behaviour was detected when resources came from personal funds and debt capital: Relationships between management practices and debt capital present themselves positively, indicating that obtaining credit from these sources is associated with increased use of tools.
\end{abstract}

Keywords: management practices; costs; small business.

Reference to this paper should be made as follows: de Araújo, J.G., Lagioia, U.C.T., Santos, A.A. and dos Prazeres, R.V. (2016) 'Management practices in micro and small enterprises: the relationships between practices adopted and funding', Int. J. Multivariate Data Analysis, Vol. 1, No. 1, pp.76-95. 
Biographical notes: Juliana Gonçalves de Araújo is a $\mathrm{PhD}$ student in Management at UFPE (PROPAD). She received her Master's degree in Accounting from UFPE (PPGCC). She received her Bachelor in Accounting from UFPE. She has a Master's degree dissertation with focus on management of a textile cluster.

Umbelina Cravo Texeira Lagioia is a Professor at UFPE and Advisor of Araújo during her Master's degree and $\mathrm{PhD}$. She holds a Master and $\mathrm{PhD}$ in Management (PROPAD-UFPE) and Bachelor in Accounting. She is an author of books related to international accounting and financial market.

Aldemar de Araújo Santos is a Professor at UFPE. She is a Co-Supervisor of Araújo during her Master's Degree. $\mathrm{PhD}$ at Minho University (Portugal). Bachelor's and Master's degree in Computer Science at UFPE. She is an author of books related to information systems and enterprises.

Rodrigo Vicente dos Prazeres is a PhD student in Accounting at UFPE. He received his Master's degree in Accounting from UFPE. He received his Bachelor's degree in Accounting from UNICAP-PE. His area of interest is finance and market.

This paper is a revised and expanded version of a paper entitled 'Management practices in micro and small enterprises: the relationships between practices adopted and funding' presented at XVI USP International Conference in Accounting, São Paulo, 27-29 July 2016.

\section{Introduction}

Small organisations have increasing significance in the environment of both developed and emerging countries, gaining attention for their ability to create jobs producing significant effects on the economy. In 2013, these companies represented in Brazil 98.2\% of formal enterprises, $52.1 \%$ of total existing jobs and $41.4 \%$ of wages (SEBRAE, 2014).

Studies on small businesses began in a seminal manner through the work of Christensen (1953). The author demonstrated that small and medium enterprises had specific characteristics such as a high degree of power centralisation, management and ownership. According to Ribeiro et al. (2012) only in the 1980s interest in research related to the theme emerged. Boocock (1990) attributes to Bolton Committee the pioneering initiative to provide detailed information on the financing of small businesses in the UK in 1970.

Since then, various themes on the segment have been developed, for instance the remuneration of managers of small companies (Watson, 1994a, 1994b; Watson et al., 1996), the process of internationalisation (Calof and Viviers, 1995), the use of information systems and technology (Lim and Goh, 1995; McGregor and Gomes, 1999), training and human resources (Wong et al., 1997), local area networks (Paniccia, 1998), gender (Mukhtar, 1998) successfulness (Lin, 1998) and innovation (Motwani et al., 1999). Particularly, in the area of accounting and finance access to credit, the lack of skilled labour, high taxes and deficiency in understanding financial accounting and management practices are areas that have been explored (Stroeher and Freitas, 2008). Other studies emphasise the difficulty that managers have to even take notice of management practices (Albuquerque, 2004; Lucena, 2004; Miranda et al., 2008; Moreira et al., 2013). 
In the international context, the recent work of López and Hiebl (2015) analysed the factors related to a greater or lesser use of financial tools in small and medium size enterprises. The size of the enterprises, its location in developing countries, lack of access to resources (Benjaoran, 2009; Hudson et al., 2001) the limited availability of credits (Brierley, 2011; Chand and Dahiya, 2010; Howorth and Westhead, 2003; Laitinen, 2011; Marriott and Marriott, 2000) and a high influence of the family on business (Alattar et al., 2009; Lema and Duréndez, 2007; Neubauer et al., 2012) are associated with lower use of accounting practices.

Accounting and management tools, when used, normally stem from legal or contractual obligation, and not for the purpose of obtaining a better decision-making process. In this sense, stakeholders produce significant influence on the management strategies adopted by micro and small enterprises. Cancellier (2000) cites the banks as one of the main stakeholders of these organisations and demonstrates how managers of small businesses seek to meet the demands imposed by the banking system. He also notes the lender position is usually assumed by the own business partners, their family members or even the government.

Aware of the strong influence of stakeholders in conducting business, of the limited resources available and the limited knowledge management in small businesses, this study aims to verify the relationship between the different sources of financing and the management practices adopted by micro and small companies in a textile cluster in Brazil. It should be noted that the creation and development of clusters, composed mainly of small businesses, have, according to Domingues and Paulino (2009), Demajorovic and Silva (2010) and Ribeiro et al. (2012), an invaluable stimulus for regional and local growth.

Given the importance of regional characteristics, the study aims to investigate the relationship between funding and the use of management accounting practices. The emphasis is on small business in Brazil, given that there is a gap in the literature on this topic. This study contributes to the understanding of the influences of external characteristics in the internal managing the organisation.

This paper can contribute to understanding how management control practices are adopted, as well as what are the main sources of financing of micro and small enterprises in the context of a cluster. It also intends to expand the literature review regarding the funding of micro and small business and how these funding sources are related to the characteristics of management control. Such analysis may provide useful information to help the banks and financial institutions to be more close to small businesses, offering them more customisable services and reducing credit-access bureaucracy by offering credit lines adapted to this environment. Finally, the differences found between the aforementioned relationships can also help to understand the influence of family on business management.

\section{Literature review}

\subsection{Capital structure and small business financing}

One of the most basic decisions of an organisation is its capital structure or its financing decisions. Authors such as Modigliani and Miller (1958) have given a contemporary approach to studies focused on the capital structure through the analysis of its effects on 
the value of organisations. Authors such as Myers (1984), Myers and Majluf (1984) and Kim (1978), trying to understand the factors that influence a company's capital structure, deepened the theme with the trade-off theory and the pecking order theory. According to the trade-off theory, companies seek for an optimal level of debt, balancing between tax benefits and bankruptcy costs, whereas in the pecking order theory organisations seek debt when funds internally generated are insufficient, being the external resources the last resort.

However, assumptions of this theory, e.g., the efficient and rational market hypothesis and the search for maximum profit, leads to a scenario sometimes not applied to small businesses, or even ignored by studies in finance, as stated by Keasey et al. (2015). Many of these papers do not consider, for example, the various limitations that these organisations have, such as restricted access to capital and high sensitivity to external events (Chaganti et al., 1995).

According to these authors, small businesses do not usually look for outside capitals as large companies do, especially because, in those, the role of the manager is associated with the owner's figure, which prefers to safeguard its influence in the company's decision process (Barton and Matthews, 1989; Levin and Travis, 1987). Furthermore, unlike what the theory predicts about the tax benefits of debt, small businesses do not make use of this feature because they have lower benefits than those of large organisations (McConnell and Pettit, 1984). Finally, small businesses have less ability to take risk of failure compared to larger ones.

In some places, however, the motivation to avoid external capital from financial institutions is more related to cultural aspects. In the cluster of Santa Cruz do Capibaribe and other cities, for example, the influence of family is significant and obtaining resource from this source is considerable more reliable, in addition to reducing the risk of high interest rates. During the survey, some of the micro and small businesses owners informed that many successful people did not borrow from banks and that this is also the reason why they too went well.

Therefore, small businesses, in the same way that youngest companies, regularly resort to funding sources of family origin, to commercial credit (trade credit) and to angel investors (business angel finance), as indicated by Berger and Udell (1998). Romano et al. (2001), analysing the capital structure of family businesses, strengthen this connection by negatively relating the time of existence of a company with getting family loans.

Serrasqueiro and Nunes (2014) also found that small hotel companies in Portugal have, as external sources of capital, funds deriving from the very owner, friends or family, especially given the restriction of access to the capital market, as confirmed by Ang (1992).

Nevertheless, these results do not necessarily confirm a widespread tendency of lower use of bank financing. A report published in 2012 shows that the capitalisation through financial institutions represented the main source of financing for small and medium-sized eurozone firms, being $33 \%$ related to bank loans and $41 \%$ arising from lines of credit, as pointed out by Nogueira da Silva and Braga (2014). Still, the authors seem to indicate the difficulty of small business to obtain funding from government and official financial institutions rests, in many cases, on the absence of adequate and formal accounting control and the higher risk of default. La Torre et al. (2010) had already come to the similar conclusion, adding that this difficulty is accentuated in emerging countries, 
possibly because of the greater centralisation of the banking system and lower adaptation of services to small businesses. The study of Parisotto and Rosa (2005) found that $90 \%$ of SMEs is financed from own resources, and that, although $50 \%$ of the sample were fund-raised through banks, these were focused on working capital.

Given the variety of funding sources, Mizumoto et al. (2010) sought to identify factors that may be related or not to the business survival in an emerging economy. These factors include the capital stock, or origin of the resources, human capital and management practices. The authors observed that both in a logistic prediction model, as in the Cox bankruptcy prediction model, applying founders' own resources or those originated from family or friends has no significance, in contrast to results obtained from 'management practices' analyses.

In Brazil, Miranda et al. (2008) revealed that $57.6 \%$ of small grocery stores tend not to seek to financial institutions to obtain funding. One of the reasons may be the low customisation of services for the small business sector (Vilella and Soares, 2009). The study by Silva et al. (2014) suggested that access to finance is one of the three most important factors considered by small businesses.

In order to verify the funding decisions in family businesses, Keasey et al. (2015) found that family businesses with large participation of the owner tend to use more debt in order to not dilute the control, and this result is more significant to younger companies. Financial institutions expect the loans to have payment guarantee, requiring a demonstration of solvency capacity. In turn, relatives or family members tend not to require statements and reports to comprehend the financial situation. Both sources are distinguished, principally, by the degree of payment enforceability. The companies operate in accordance with the requirements of each source, performing the corresponding procedures or practices.

The necessity to report to an interested party, be it bank, government, partners or relatives, can trigger changes in the organisation's management or the adoption of specific practices. Based on this assumption, this study addresses the management practices and their applications to small business.

The cities in the cluster of this study have a generally low level of education, what could be related to the reduced knowledge of financing and organisational control. Besides, during the application of the questionnaire, many told that banks were not a reliable funding source. Most of the surveyed never had had contact with a bank or other financial institution. This could be motivated by the small number of banks that have small business as their targets.

In this region, banks that stimulate the economic development are more present, such as the Banco do Nordeste (BNB) and Banco Nacional de Desenvolvimento (BNDES). Both of these banks recently promoted a seminar promoting reduced interest rates to micro and small business, but it did not have significant impact. Previous studies disclosed that this may be related to the distance between the institutions and the businesses owners involving cultural aspects (risk aversion, rational or not), in addition to the limited access to attractive options for small business.

This study aims to verify the relationship between funding sources and management practices in order to provide reflection about better possibilities and strategies for micro and small businesses management. 


\subsection{Management practices in small business}

The studies on management practices reveal extensive use of variables related to cash management, cost, strategy, people management, and even the technology employed. Thus, despite the immediate association with aspects of organisational control, this topic is not limited to a study of monitoring tools in organisations, but also part of the business strategy as a field of study (Souza and Clemente, 1998), giving support to companies and managers to choose a decision profile.

Melo and Leone (2015), exploring management practices related to cost, showed that $91 \%$ of the sample - 49 small industries in a Brazilian city - calculated the production costs. Furthermore, among the costing methodologies (ABC, variable or absorption), the absorption was the most used, and the budget was implemented by $86 \%$ of respondents. In addition, almost all of the companies (93\%) used costs as a basis for setting sales prices, combined or not with mark-up and market prices analysis. In contrast, the work of Parisotto and Rosa (2005) found that $25 \%$ of a sample of small businesses did not use formulas to calculate the selling price, while $11.8 \%$ used only costs and $66.6 \%$ adopted the mark-up multiplier.

Carlos Filho (2014) used a Brazilian horticulture and viticulture cluster as sample to observe a greater use of management tools and a greater concern with management, which may be related to the larger-sized nature of the companies in this sample and the greater relevance of exporting activities. Silva Filho (2014) examining a Brazilian plaster cluster, noticed a dominant presence of smaller companies and a lower adoption of management practices. Similar to these findings, the work of Araújo (2015), performed in a garment cluster, also identified low utilisation of management artefacts, despite a greater focus on cash control and simple costs controls.

A study in Germany conducted by Lohr (2012) similarly observed a trend of limited use of accounting and management tools. The author noted that the application of these practices is scarce because managers do not believe that the benefits outweigh the costs, and consider their position in the market stable regardless of using such tools.

The importance committed to less robust tools was also depicted in a study by Lima and Imoniana (2008), which, examining a group of companies in other regions of Brazil, found that respondents attach more importance to cash management, accounts payable and receivable and control of costs, in that order.

Although micro and small businesses usually do not demand advanced management practices, studies have confirmed the relevance of certain practices for the success of the enterprise. Santos et al. (2016), as well as Ruengdet and Wongsurawat (2010), studied small businesses that were successful (57) and not successful (37) in Thailand, and highlighted two results in the first group:

a tendency to have a clear and systematic division of work performed

b tendency to establish control through regular accounting records, especially related to costs and expenses

c tendency to develop business and marketing plans.

These data are in line with the findings of Švárová and Vrchota (2013) who comparing 176 companies in the Czech Republic suggested that small and medium companies that established clear strategies demonstrated better financial performance compared to those that did not. Santos et al. (2016) recently furthered this relationship. 
Still, the level of adoption of management practices can also be related to business characteristics other than size. Studies suggest that the source of funding can be one of them. Deloof and Jegers (1999) and Camargos et al. (2010) indicate that the use of external funding sources is positively associated with the application of working capital management and cash management. Carvalho and Schiozer (2012), however, did not find the same results and claimed that this relationship cannot be confirmed in Brazil, because external funding tends to be sporadic in the country.

Other surveys have revealed a possible relationship of the use of practices with the influence of the family. Garcia Perez de Lema and Duréndez (2007) showed a trend of non-use of accounting practices by organisations with strong family influence, suggesting a negative association.

It is expected to provide similar contributions in the specific environment of a textile cluster and to find out what characteristics (such as funding sources) are related to how the owners conduct their businesses in terms of management control practices. This study focuses on practices like cash management, costing control, report elaboration and analysis and other relevant managerial tools.

This study has the advantage of comprehending similar industries in the same region, with similar management, size and ownership profile. This region is also completely dependent on textile and clothing activities; therefore, an inadequate management, for its systematic effect, can affect negatively the development and economic growth of the area.

\section{Methodology}

\subsection{Sample}

This paper chooses to narrow the management practices to those studied in management and costs accounting. The sample consists of companies located in a large cluster of textile manufacturing in the State of Pernambuco, Brazil, which covers several cities and has been growing significantly for the past years.

The cluster is formed by many cities (Caruaru, Toritama, Santa Cruz do Capibaribe, Brejo da Madre de Deus and six more). It is unknown how many industries are in this cluster. There is an estimative of 18,800 enterprises, of which $19 \%$ are formal. This number, however, does not distinguish between types of businesses (industrial, wholesale etc.). The informality also leads to many owners not agreeing to reveal information about their businesses, since they are afraid of being observed, in fact, by local authorities. These issues influenced the sample, which consisted in 52 industries located in Santa Cruz do Capibaribe, Caruaru and Toritama.

Others types of enterprises were not considered because this research targets to identify businesses that contains production process and more complex activities, since these are normally associated with a higher use of management controls.

\subsection{Data}

The data was obtained through a questionnaire with questions related to the profile of the respondents, the profile of their firms and to management practices. Due to the large time spent with each respondent, it was also possible to obtain comments and opinions about 
their management practices, which, at times, became relevant to the analysis. The questionnaires were applied from June to August 2014. The questions were structured in order to understand the frequency, or sometimes the relevance, of each variable as exposed in Table 1.

The questions were based mainly on previous studies that examined the control practices and the use of management tools by companies, especially in the Brazilian context. These studies are listed in Table 1.

Table 1 Questionnaire structure

\begin{tabular}{lc}
\hline Drivers & Authors \\
\hline $\begin{array}{l}\text { Cost of raw materials } \\
\text { Production costs } \\
\text { Budgets use and elaboration }\end{array}$ & $\begin{array}{c}\text { Braga et al. (2010) } \\
\text { Coullado et al. (2003) and Almeida et al. (2012) } \\
\text { Guilding et al. (1998), Machado and Souza (2006) and } \\
\text { Almeida et al. (2012) }\end{array}$ \\
$\begin{array}{l}\text { Standard cost use } \\
\text { Sale price formation } \\
\text { Breakeven }\end{array}$ & $\begin{array}{c}\text { Souza et al. (2003), Marie et al. (2010), Badem (2013), } \\
\text { Costing method } \\
\text { Contribution margin et al. (1998) and Joshi (2001) } \\
\text { Braga et al. (2010) and Machado and Souza (2006) } \\
\text { Strategic management } \\
\text { Souza et al. (2003) and Hofer et al. (2006) } \\
\text { Souza et al. (2003) and Machado and Souza (2006) } \\
\text { Souza et al. (2003), Machado and Souza (2006), } \\
\text { Hofer et al. (2006) and Almeida et al. (2012) } \\
\text { Cash management }\end{array}$ \\
\hline
\end{tabular}

Respondents could answer whether they used such practices, which were used, and with what frequency.

\subsection{Treatment of data}

To answer the question and objective of this research, tests that can disclose the relationships between the variables were applied. However, the nature of data does not allow the use of parametric tests. This is also related to the structure of questions, because most of them were in Likert scale. The number of observations (52) also influenced this limitation, since it was sometimes necessary to transform the data in binary variables to enable the correct use of tests and to allow sufficient observations to compute significance of the tests.

Thus, the data did not show a symmetrical behaviour, dissociating from the hypothesis of normality, as confirmed by the Kolmogorov-Smirnov test performed. Consequently, it was applied the non-parametric Mann-Whitney U test, which serves as an alternative to the student t-test and bases its analysis on medians. Additionally, Pearson and Spearman correlations were used to check the direction of the associations. 


\section{Data analysis}

Although the selected studies on small business capital structure are generally limited to the analysis based on data of debt and taxes, this study focuses on the gap of the peculiar composition of the capital structure of these companies in a cluster scope.

To verify the differences in management practices in relation to the type of source of funding, this study sought to segregate sources into two groups: debt capital and equity/internal.

The debt capital comprehends sources mainly characterised by the occurrence of interest, such as the funds rose through banks, credit institutions and other forms of financing. In turn, 'equity/internal' includes the funds obtained through personal connections of the manager (partner). Figure 1 illustrates the composition of capital structure of the companies of the sample. This term is considered equity or internal since resources from owner can be taken as internal resources. Thus, this term absorbs all non-debit forms.

Figure 1 Capital structure of the clothing cluster SMEs (see online version for colours)

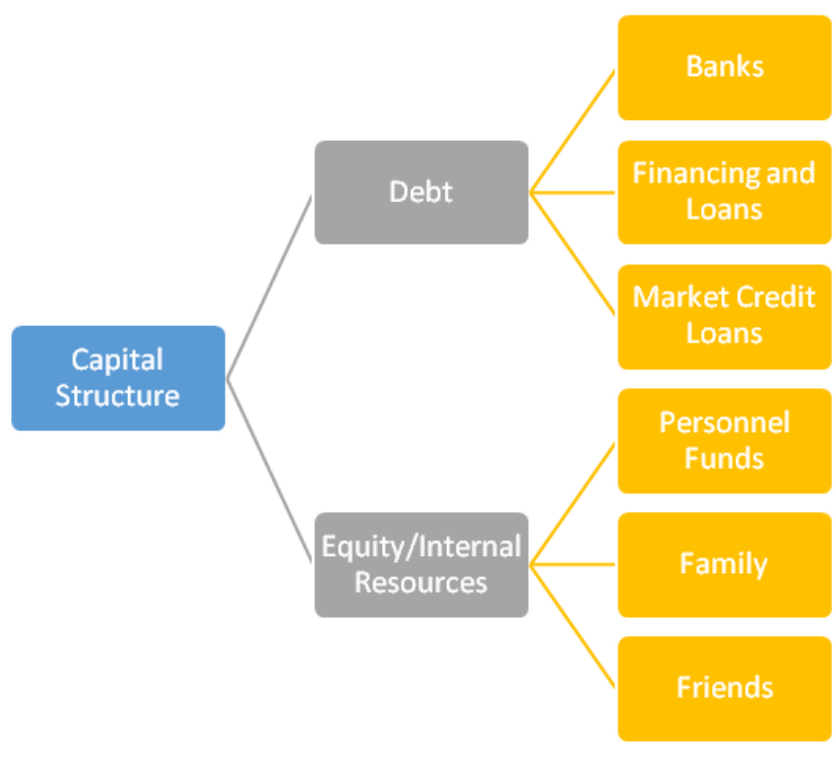

The data demonstrate that most business starts with the help of family resources or with the personal resources of the owner: $38.5 \%$ of companies used family assistance to start the business, while $42.3 \%$ used personal funds. Only $15 \%$ of respondents said that make use of a source of credit, such as loans or overdraft. $34 \%$ said they rely on banks as a source of subsequent resources, i.e., resources used during the course of business, and $21.2 \%$ use personal resources to continue the business. Most of the enterprises of this sample use resources from family or from owners to start its activities, and during the course of business increases the use of external funding according to the confidence of the owners/managers. This result is aligned with Serrasqueiro and Nunes (2014).

Considering the possible relationships between management practices and fund-raising by small companies, this study presents the following hypothesis: 
$\mathrm{H}$ The source of funding has significant relationships with the use of management controls.

To verify this hypothesis, the questionnaire used Likert scale to the variables related to management control practices and binary variables to evaluate the funding sources. One of the reasons to use this method was the difficult found in obtaining answers to open questions or questions that intended to identify numbers (sales, expenses, profit, amount of resources from family and other funds, etc.). This perception was just realised during the application of the pilot questionnaire.

\subsection{Equity/internal sources}

The first analysis to verify the correlations between the instruments of control derives from the variable "family, personal background and friends as initial and subsequent funding sources". The results are displayed in Table 2.

Table 2 Mann-Whitney U test for family as subsequent resources source

\begin{tabular}{|c|c|c|c|c|c|}
\hline & Demons $^{\mathrm{a}}$ & Prod.Cost ${ }^{b}$ & $\mathrm{Budget}^{\mathrm{c}}$ & Mark.Pric ${ }^{\mathrm{d}}$ & CostMethod \\
\hline Mann-Whitney U & 84.000 & 124.000 & 121.500 & 138.000 & 103.500 \\
\hline Wilcoxon W & 129.000 & 169.000 & 166.500 & $1,084.000$ & 148.500 \\
\hline Z & -2.737 & -1.942 & -2.178 & $-2,629$ & -2.583 \\
\hline \multirow[t]{2}{*}{ Asymp. sig. (2-tailed) } & .006 & .052 & .029 & .009 & .010 \\
\hline & C.Margin $^{\mathrm{f}}$ & CshMngmt ${ }^{\mathrm{g}}$ & CshFlo $^{\mathrm{h}}$ & SalTerm $^{\mathrm{i}}$ & CashBudg ${ }^{\mathrm{j}}$ \\
\hline Mann-Whitney U & 139.500 & 117.500 & 110.500 & 108.500 & 130.500 \\
\hline Wilcoxon W & 184.500 & 162.500 & 155.500 & 153.500 & 175.500 \\
\hline Z & -1.790 & -2.519 & -2.346 & -2.388 & -1.983 \\
\hline Asymp. sig. (2-tailed) & .074 & .012 & .019 & .017 & .047 \\
\hline \multicolumn{6}{|c|}{$\begin{array}{l}\text { Notes: }{ }^{\mathrm{a}} \text { Demonstratives. } \\
{ }^{\mathrm{b}} \text { Production. } \\
{ }^{\mathrm{c}} \text { Costs budget. } \\
{ }^{\mathrm{d}} \text { Market price. } \\
{ }^{\mathrm{e}} \text { Costing methods. } \\
{ }^{\mathrm{f}} \text { Contribution margin. } \\
{ }^{\mathrm{g}} \text { Cash management. } \\
{ }^{\mathrm{h}} \text { Cash flow. } \\
{ }^{\mathrm{i}} \text { Sales terms. } \\
{ }^{\mathrm{j}} \text { Cash budget. }\end{array}$} \\
\hline
\end{tabular}

The fact that the subsequent source of resources comes from family origin has relationship with the use of management controls. The first is the use of statements: those who do not use family resources make more use of statements. The same negative relationship can be applied to the measurement of production costs, budget, cash management, cash flow, contribution margin* and cash budget. It is worth noting that the contribution margin only has significance at $10 \%$.

Regarding the sales practices, companies with family funding have positive relationship with the use of market prices to determine the value of products and to define a smaller deadline for the receipt of sales. Such firms do not usually negotiate the terms of receipt, often applying the market price method instead of the cost plus profit approach 
to define the value of their products. Though some respondents claimed that the market price was 'not the best method', they did not know how to properly determine the value using the calculation of costs, even if, according to them, it was the 'correct' method.

In relation to family support as a source of initial resources, four variables presented significant relationships, namely: budget*, contribution margin, cash management and cash budget. Only budget showed marginal significance.

Table 3 Mann-Whitney U test for family as initial resources source

\begin{tabular}{lcccc}
\hline & Budget & Contribution margin & Cash management & Cash budget \\
\hline Mann-Whitney U & 238.000 & 226.000 & 190.000 & 232.000 \\
Wilcoxon W & 448.000 & 436.000 & 400.000 & 442.000 \\
Z & -1.929 & -2.422 & -2.553 & -2.154 \\
Asymp. sig. (2-tailed) & $.054^{*}$ & .015 & .011 & .031 \\
\hline
\end{tabular}

All these relationships show a negative correlation, indicating that the fact of obtaining financing through family implies lower usage of tools.

When observing the personal fund as a subsequent source of resources, only four variables were statistically representative: budget, cash budget, cash flow, and, related to sales, market price plus profit margin, as shown in Table 4. It should be noted that two of the variables (cash flow and budget) * showed marginal significance (above 5\%).

Table 4 Mann-Whitney U test for personnel fund as a subsequent source of resources

\begin{tabular}{lcccc}
\hline & $\begin{array}{c}\text { Market price plus } \\
\text { profit margin }\end{array}$ & Cash flow & Cash budget & Budget \\
\hline Mann-Whitney U & 137.000 & 156.500 & 120.500 & 157.500 \\
Wilcoxon W & 998.000 & $1,017.500$ & 981.500 & $1,018.500$ \\
Z & -2.440 & -1.806 & -3.062 & -1.906 \\
Asymp. sig. (2-tailed) & .015 & $.071^{*}$ & .002 & $.057^{*}$ \\
\hline
\end{tabular}

However, the trend of the correlation inverted its direction, indicating increased use of management accounting systems. Moreover, firms tend to use the market price method to set the value of the product, alone or in conjunction with a profit margin on the calculated cost. Potential associations with the use of personal fund to initiate business were also found, as shown in Table 5.

Table 5 Mann-Whitney U test for personal fund as an initial source of resources

\begin{tabular}{lcc}
\hline & Low cost strategy & Cash management \\
\hline Mann-Whitney U & 216.000 & 243.500 \\
Wilcoxon W & 651.000 & 708.500 \\
Z & -2.289 & -1.673 \\
Asymp. sig. (2-tailed) & .022 & $.094^{*}$ \\
\hline
\end{tabular}

Only the adoption of low-cost strategy offered significance, while the cash management falls as marginally significant. Table 7 demonstrates that respondents who used personal funds as an initial source tend to have a low-cost strategy, and show evidence of use of cash management. 
The variable 'friends' had not been offered as an alternative in the questionnaire, but was included by the very appointment of the respondents.

Table 6 Mann-Whitney $U$ test for friends as a subsequent source of resources

\begin{tabular}{lcc}
\hline & Cash management & Cash flow \\
\hline Mann-Whitney U & 69.500 & 68.500 \\
Wilcoxon W & 84.500 & 83.500 \\
Z & -2.041 & -1.777 \\
Asymp. Sig. (2-tailed) & .041 & $.076^{*}$ \\
\hline
\end{tabular}

Table 7 Source of funds - equity/internal

\begin{tabular}{llcc}
\hline Source of resources & & Association & Pearson correlation \\
\hline Family & Statements (Demons.) & - & $-.383(0.000)$ \\
& Production cost (ProdCost) & - & $-.272(0.051)$ \\
& Budget & - & $-.305(0.028)$ \\
& Costing method (CostMethod) & - & $-.362(0.008)$ \\
& Contribution margin (C.Margin) & - & $-.251(0.073)^{*}$ \\
& Cash management (CshMngmnt) & - & $-.353(0.010)$ \\
& Cash flow (CshFlo) & - & $-.328(0.017)$ \\
& Cash budget (CashBudg) & - & $-.278(0.046)$ \\
& Market price (Mark.Pric) & + & $.368(0.007)$ \\
& Sales terms (SalTerm) & - & $-.321(0.020)$ \\
\hline Family & Budget & - & $-.270(0.053)^{*}$ \\
& Contribution margin & - & $-.339(0.014)$ \\
& Cash management & - & $-.348(0.011)$ \\
& Cash budget & - & $-.302(0.030)$ \\
\hline Personal fund & Budget & + & $.267(0.056)^{*}$ \\
(initial source) & Market price plus profit margin & + & $.342(0.013)$ \\
\hline Friends & Cash budget & + & $.429(0.002)$ \\
& Cash flow & + & $.253(0.070)^{*}$ \\
\hline & Cow cost strategy & + & $.327(0.020)$ \\
& Cash management & + & $.248(0.076)^{*}$ \\
\hline & Cash flow & $-.286(0.040)$ \\
& & $-.249(0.075)^{*}$ \\
\hline
\end{tabular}

As observed in the variable 'family', 'friends' as a source of resources leads to a tendency of not using management practices, although only in two of them can be confirmed a statistically significant association, and marginal one in the case of cash flow. The negative correlation between the variables can be seen in Table 7 .

The summary of the associations is displayed in Table 7, where the direction of the correlations is exposed, as well as the results obtained using the Pearson correlation and its respective $\mathrm{p}$-values. 
Table 7 reveals that, albeit there is a difference between the use of certain management tools among those who obtained funds through personal and family sources, the level of use of the practices has a negative correlation with most of the variables. Hence, one may indicate that funds obtained without encumbrance lead to less use of management tools, despite a slight difference concerning personal funding.

The results are aligned with the studies developed by Alattar et al. (2009), Lema and Duréndez (2007) and Neubauer et al. (2012), in which family influenced negatively the use of management accounting practices and controls. As it can be seen, this study presented a similar behaviour when friends were used as funding source. This research also took into account the influence of family in obtaining resources, whether other studies only considered the influence on management.

\subsection{Debt sources}

Debt capital is represented mainly by banking fund-raising (34\% of respondents), though it also includes loans and credits provided by financial institutions.

Table 8 shows that banks are associated with the use/preparation of statements, production costs*, profit margin and the selling price method by market prices plus profit margin.

Table 8 Mann-Whitney U test for bank as subsequent source of resources

\begin{tabular}{lcccc}
\hline & Statements & Production cost & Profit margin & $\begin{array}{c}\text { Market price plus } \\
\text { profit margin }\end{array}$ \\
\hline Mann-Whitney U & 199.500 & 226.500 & 193.000 & 205.000 \\
Wilcoxon W & 794.500 & 821.500 & 788.000 & 376.000 \\
Z & -2.117 & -1.655 & -2.511 & -2.391 \\
Asymp. Sig. (2-tailed) & .034 & $.098^{*}$ & .012 & .017 \\
\hline
\end{tabular}

The results presented in the table referred to those associations that were significant, and through these it is possible to observe a difference in the use of statements, the measurement of the cost of production and the method of setting the values of the products.

According to Table 11, those firms where the resource comes from banks show a positive association with the use of statements, and only at $10 \%$ significance level, also with the measurement of production costs. As for the definition of the method of pricing, the profit margin (i.e., using costs plus a profit margin) is the most widely used approach. Some of the respondents said that this practice was satisfactory, because, despite using the sale price, a method considered 'not suitable' for them, somehow they would use the product cost for price setting.

This aversion to uncertainty in sales prices is also seen in the negative correlation between companies with bank resources and the 'market price plus profit margin' practice, contrary to what was found in the previous section (personal fund). There were also found significant associations with the credit market. 
Table 9 Mann-Whitney U test for credit as subsequent source of resource

\begin{tabular}{lcccc}
\hline & Budget & Costing method & Contribution margin & Cash budget \\
\hline Mann-Whitney U & 31.500 & 66.500 & 95.500 & 76.500 \\
Wilcoxon W & $1,066.500$ & $1,101.500$ & $1,130.500$ & $1,111.500$ \\
Z & -4.225 & -2.808 & -2.277 & -2.826 \\
Asymp. sig. (2-tailed) & .000 & .005 & .023 & .005 \\
\hline
\end{tabular}

All variables showed statistical significance: budget, use of costing method, contribution margin and cash budget. In all cases, as seen in Table 11, there is a positive correlation between this type of source of resources and the use of management practices.

It also tested the credit as the first resource in order to understand if such significances also exist. As seen in Table 10, it was obtained an association with budget and costing method.

Table 10 Mann-Whitney U test for credit as initial source of resources

\begin{tabular}{lcc}
\hline & Budget & Costing method \\
\hline Mann-Whitney U & 14.000 & 18.000 \\
Wilcoxon W & $1,289.000$ & $1,293.000$ \\
Z & -2.142 & -1.807 \\
Asymp. Sig. (2-tailed) & .032 & $.071^{*}$ \\
\hline
\end{tabular}

Despite costing method, in this case, being marginally significant, budget, as in the case subsequent sources, presented a significance level below 5\%. In both cases, the credit indicated a positive association with such practices (Table 11).

Table 11 Subsequent source of resources - debt capital

\begin{tabular}{llcc}
\hline \multirow{2}{*}{ Source of resources } & & Association & $\begin{array}{c}\text { Correlation } \\
\text { Pearson/Spearman }\end{array}$ \\
\hline Bank & Statements & + & $.296(0.033)$ \\
& Production cost & + & $.232(0.098)^{*}$ \\
& Profit margin & + & $.352(0.011)$ \\
& Market price plus profit margin & - & $-.335(0.015)$ \\
\hline Credit & Budget & + & $.592(0.000)$ \\
& Costing methods & + & $.383(0.005)$ \\
& Contribution margin & + & $.319(0.021)$ \\
& Cash flow & + & $.396(0.004)$ \\
\hline Credit & Budget & + & $.300(0.031)$ \\
(initial resource) & Costing methods & + & $.253(0.070)^{*}$ \\
\hline
\end{tabular}

Even though these sources of resources did not disclose many significant associations as what was exposed in the source of funds through equity/internal, it is clear that there is an indication of increased use of tools of control when the capital is burdensome and interest is incurred. 
During the application of questionnaire, it could be perceived that the respondents, in general, have qualms about resorting to banks and only do so when there is no other option, mainly due to high interest rates and to payment capacity requirements.

As it can be observed in Table 11, when managers use external funding they show higher use of management control practices. This relationship is also demonstrated in the studies conducted by Deloof and Jegers (1999) and Camargos et al. (2010).

Another study developed by Anjos et al. (2012) in Brazil observed if better reports and management were related to more credits approvals from banks, and concluded that, for some owners, accounting reports were not always the best option to ensure obtaining credit.

\section{Conclusions}

The aim of this study was to verify the existence of relationships between management practices and the source of funds obtained by companies, since previous studies have found evidence of influence from sources in the management approach.

Some studies suggest that small businesses have limited access to credit, either because of their own management characteristics or the low customisation of services by financial institutions, though Deloof and Jegers (1999) propose the existence of a positive relationship between management practices and obtaining external funding. Additionally, when the family is involved with the management, be it through financial aid or by exercising family control, there is evidence of a less systematic management, as suggested by Lema and Duréndez (2007).

Based on these characteristics, this study used the data obtained through questionnaires applied in a textile cluster, characterised by the predominance of micro and small enterprises, in an emerging economy setting. It could be observed that sources of resources of family origin, classified as equity/internal sources, showed significant negative associations with the management and control practices scrutinised in this study. When analysing 'personal funds' as source of capital, a different behaviour was detected, indicating a proximity to the characteristics of a resource generated internally by the company. This hypothesis can be substantiated by the high concentration of organisations in the hands of the owner/manager, where most of respondents claim to disregard the business entity concept.

When the resources came from debt capital, a different behaviour was shown. Relationships between management practices and debt capital present themselves positively, indicating that obtaining credit from these sources is associated with increased use of tools.

One limitation of this study is the reduced amount of questionnaires obtained. This amount prevents a more robust data analysis, preventing, for example, the verification of the dependency relationships between variables.

Nevertheless, this study intends to contribute to further work with its observation of the influence of the source of resources on small business. The authors expect to expand the sample and improve the collection instrument to support the existence of dependency relationships, and also increasing the control variables applied in the study. 


\section{References}

Aksoylu, S. and Aykan, E. (2013) 'Effects of strategic management accounting techniques on perceived performance of businesses', Journal of US-China Public Administration, Vol. 10, No. 10, pp.1004-1017.

Alattar, J.M., Kouhy, R. and Innes, J. (2009) 'Management accounting information in micro enterprises in Gaza', Journal of Accounting \& Organizational Change, Vol. 5, No. 1, pp.81-107.

Albuquerque, A.F. (2004) Gestão Estratégica das Informações Internas na Pequena Empresa: estudo comparativo de casos em empresas do setor de serviços (hoteleiro) da região de Brotas-SP, Dissertação (Mestrado em Engenharia da Produção) - Escola de Engenharia de São Carlos, Universidade de São Paulo, São Carlos.

Almeida, L.B., Machado, E.A. and Panhoca, L. (2012) 'Práticas de Gestão de Custos e Perspectivas Estratégicas: um estudo na indústria da construção do Estado do Paraná', Revista Brasileira de Gestão de Negócios, Vol. 14, No. 44, pp.353-368, São Paulo.

Ang, J.S. (1992) 'On the theory of finance for privately held firms', Journal of Small Business Finance, Vol. 1, No. 3, pp.185-203.

Anjos, L.C.M., Miranda, L.C., Silva, D.J.C. and Freitas, A.R.F. (2012) 'Uso da Contabilidade para Obtenção de Financiamento pelas Micro e Pequenas Empresas: Um Estudo a Partir da Percepção dos Gestores', Revista Universo Contábil, Vol. 8, No. 1, pp.86-104.

Araújo, J.G. (2015) Utilização das informações gerenciais para tomada de decisão: um estudo exploratório no arranjo produtivo local de confecção do estado de Pernambuco, Dissertação (Mestrado em Ciências Contábeis) - Universidade Federal de Pernambuco, Recife.

Barton, S.L. and Matthews, C.H. (1989) 'Small firm financing: implications from a strategic management perspective', Journal of Small Business Management, Vol. 27, No. 1, pp.1-7.

Badem, A.C. (2013) 'Is standard costing still used? Evidence from Turkish automotive industry', International Business Research, Vol. 6, No. 7, pp.79-90.

Benjaoran, V. (2009) 'A cost control system development: a collaborative approach for small and medium-sized contractors', International Journal of Project Management, Vol. 27, No. 3, pp.270-277.

Berger, A.N. and Udell, G.F. (1998) 'The economics of small business finance: the roles of private equity and debt markets in the financial growth cycle', Journal of Banking \& Finance, Vol. 22, Nos. 6-8, pp.613-673.

Boocock, G. (1990) 'An examination of non-bank funding for small and medium-sized enterprises in the UK', The Service Industries Journal, Vol. 10, No. 1, pp.124-146.

Braga, D.P.G., Braga, A.X.V. and Souza, M.A. (2010) 'Gestão de Custos, preço e resultados: um estudo em indústrias conserveiras do Rio Grande do Sul', Contabilidade, Gestão e Governança, Vol. 13, No. 2, pp.20-35.

Brierley, J.A. (2011) 'A comparison of the product costing practices of large and small- to medium-sized enterprises: a survey of British manufacturing firms', International Journal of Management, Vol. 28, No. 4, pp.184-193.

Callado, A.L.C., Miranda, L.C. and Callado, A.A.C. (2003) 'Fatores Associados à Gestão de Custos: um estudo nas micro e pequenas empresas do setor de confecções', Revista Produção, Vol. 13, No. 1, pp.64-75.

Calof, J.L. and Viviers, W. (1995) 'Internationalization behavior of small and medium sized South African enterprises', Journal of Small Business Management, Vol. 33, No. 4, pp.71-79.

Camargos, M.A., Camargos, M.C.S., Silva, F.W., Santos, F.S. and Rodrigues, P.J. (2010) 'Fatores condicionantes de inadimplência em processos de concessão de crédito a micro e pequenas empresas do estado de Minas Gerais', Revista de Administração Contemporânea, Vol. 14, No. 2, pp.333-352, Curitiba.

Cancellier, E.L.P.L. (2000) 'O papel dos stakeholders na formulação de estratégias e pequenos empreendimentos catarinenses', Revista de Negócios, Vol. 5, No. 2, pp.26-33. 
Cadez, S. and Guilding, C. (2008) 'An exploratory investigation of an integrated contingency model of strategic management accounting', Accounting, Organizations and Society, Vol. 33, Nos. 7-8, pp.836-863.

Carlos Filho, F.A. (2014) Gestão de custos e formação de preço de venda, gestão de caixa e gestão de riscos em arranjo produtivo local: um estudo exploratório no setor de fruticultura, Dissertação (Mestrado em Ciências Contábeis) - Universidade Federal de Pernambuco, Recife.

Carvalho, C.J. and Schiozer, R.F. (2012) 'Gestão de Capital de Giro: um Estudo Comparativo entre Práticas de Empresas Brasileiras e Britânicas', RAC, Vol. 16, No. 4, pp.518-543.

Chaganti, R., DeCarolis, D. and Deeds, D. (1995) 'Predictors of capital structure in small ventures', Entrepreneurship Theory and Practice, Vol. 20, No. 2, pp.7-18.

Chand, M. and Dahiya, A. (2010) 'Application of management accounting techniques in Indian small and medium hospitality enterprises: an empirical study', International Journal of Entrepreneurship \& Small Business, Vol. 11, No. 1, pp.25-41.

Chenhall, R.H. and Langfield-Smith, K. (1998) 'The relationship between strategic priorities, management techniques and management accounting: an empirical investigation using a systems approach', Accounting, Organizations and Society, Vol. 23, No. 3, pp.243-264.

Christensen, R.D. (1953) Management Succession in Small and Growing Enterprises, Harvard University, Boston.

Deloof, M. and Jegers, M. (1999) 'Trade credit, corporate groups, and the financing of Belgian firms', Journal of Business Finance and Accounting, Vol. 26, Nos. 7-8, pp.945-966.

Demajorovic, J. and Silva, A.V. (2010) 'Arranjos produtivos locais e práticas de gestão socioambiental: uma análise do pólo moveleiro de Arapongas', Ambiente \& Sociedade, Vol. 13, No. 1, pp.131-149.

Domingues, R.M. and Paulino, S.R. (2009) 'Potencial para implantação da produção mais limpa em sistemas locais de produção: o pólo joalheiro de São José do Rio Preto', Gestão \& Produção, Vol. 16, No. 4, pp.691-704.

Garcia Perez de Lema, D. and Duréndez, A. (2007) 'Managerial behaviour of small and mediumsized family businesses: an empirical study', International Journal of Entrepreneurial Behaviour \& Research, Vol. 13, No. 3, pp.151-172.

Guilding, C., Lamminmaki, D. and Drury, C. (1998) 'Budgeting and standard costing practices in New Zealand and the United Kingdom', The International Journal of Accounting, Vol. 33, No. 1, pp.569-588.

Hofer, E., Rauber, A.J., Diesel, A. and Wagner, M. (2006) 'Gestão de Custos Aplicada ao Agronegócio: culturas temporárias', Contabilidade Vista e Revista, Vol. 17, No. 1, pp.29-46.

Howorth, C. and Westhead, P. (2003) 'The focus of working capital management in U.K. small firms', Management Accounting Research, Vol. 14, No. 2, pp.94-111.

Hudson, M., Smart, A. and Bourne, M. (2001) 'Theory and practice in SME performance measurement systems', International Journal of Operations \& Production Management, Vol. 21, No. 8, pp.1096-1115.

Joshi, P.L. (2001) 'The international diffusion of new management accounting practices: the case of India', Journal of International Accounting, Auditing and Taxation, Vol. 10, No. 1, pp.85-109.

Keasey, K., Martinez, B. and Pindado, J. (2015) 'Young family firms: financing decisions and the willingness to dilute control', Journal of Corporate Finance, Vol. 34, pp.47-63.

Kim, E. (1978) 'A mean-variance theory of optimal capital structure and corporate debt capacity', Journal of Finance, Vol. 33, No. 1, pp.45-63.

La Torre, A., Pería, M.S. and Schmukler, S. (2010) 'Bank involvement with SMEs: beyond relationship lending', Journal of Banking and Finance, Vol. 34, No. 9, pp.2280-2293.

Laitinen, E.K. (2011) 'Effects of reorganization actions on the financial performance of small entrepreneurial distressed firms', Journal of Accounting \& Organizational Change, Vol. 7, No. 1, pp.57-95. 
Lema, D.G.P. and Duréndez, A. (2007) 'Managerial behaviour of small and medium-sized family businesses: an empirical study', International Journal of Entrepreneurial Behaviour \& Research, Vol. 13, No. 3, pp.151-172.

Levin, R.I. and Travis, V.P. (1987) 'Small company financing: what the books don't say', Harvard Business Review, November-December, pp.30-32.

Lim Yew, B. and Goh, M.H. (1995) 'Computer security issues in small and medium-sized enterprises', Singapore Management Review, Vol. 17, No. 1, pp.15-29.

Lima, A.N. and Imoniana, J.O. (2008) 'Um estudo sobre a importância do uso das ferramentas de controle gerencial nas micro, pequenas e médias empresas industriais no município de São Caetano do Sul', Revista da Micro e Pequena Empresa, Vol. 2, No. 1, pp.28-48.

Lin, C.Y-Y. (1998) 'Success factors of small and medium-sized enterprises in Taiwan: an analysis of cases', Journal of Small Business Management, Vol. 36, No. 4, pp.43-56.

Lohr, M. (2012) 'Specificities of managerial accounting at SMEs: case studies from the German industrial sector', Journal of Small Business \& Entrepreneurship, Vol. 25, No. 1, pp.35-55.

López, O.L. and Hiebl, M.R.W. (2015) 'Management accounting in small and medium-sized enterprises: current knowledge and avenues for further research', Journal of Management Accounting Research, Vol. 27, No. 1, pp.81-119.

Lucena, W.G.L. (2004) Uma contribuição ao estudo das informações contábeis geradas pelas micro e pequenas empresas localizadas na cidade de Toritama no agreste pernambucano, Dissertação (Mestrado em Ciências Contábeis) - Programa Multiinstitucional e Inter-regional de Pós-graduação em Ciências Contábeis da UNB/ UFPE/ UFPB/ UFRN, João Pessoa.

Machado, D.G. and Souza, M.A. (2006) 'Análise das relações entre a gestão de custos e a gestão do preço de venda: um estudo das práticas adotadas por empresas industriais conserveiras estabelecidas no RS', Revista Universo Contábil, Vol. 2, No. 1, pp.42-60, Blumenau - SC.

Marie, A., Cheffi, W., Louis, R.J. and Rao, A. (2010) 'Is standard costing still relevant? Evidence from Dubai', Management Accounting Quarterly, Vol. 11, No. 2, pp.1-10.

Marriott, N. and Marriott, P. (2000) 'Professional accountants and the development of a management accounting service for the small firm: barriers and possibilities', Management Accounting Research, Vol. 11, No. 4, pp.475-492.

Mbroh, J.K. (2012) 'Cash management practices of small business owners in the Cape Coast Metropolitan Area of Ghana', Asian Economic and Financial Review, Vol. 2, No. 1, pp.40-58.

McConnell, J.J. and Pettit, R.R. (1984) 'Application of the modem theory of finance to small business firms', in Horvitz and Petit (Eds): Small Business Finance: Problems in Financing of Small Businesses, Vol. 42, Part A, JAI Press, Greenwich, Conn.

Mcgregor, J. and Gomes, C. (1999) 'Technology uptake in small and medium-sized enterprises: some evidence from New Zealand', Journal of Small Business Management, Vol. 37, No. 3, pp.94-102.

Melo, M.A. and Leone, R.J.G. (2015) 'Alinhamento entre as estratégias competitivas e a gestão de custos: um estudo em pequenas empresas industriais do setor de transformação', Brazilian Business Review, Vol. 12, No. 5.

Miranda, L.C., Libonati, J.J., Freire, D.R. and Saturnino, O. (2008) 'Demanda por Serviços Contábeis pelos Mercadinhos: são os contadores necessários?', Contabilidade Vista \& Revista, Vol. 19, No. 1, pp.131-151.

Mizumoto, F.M., Artes, R., Lazarinni, S.G., Hashimoto, M. and Bedé, M.A. (2010) 'A sobrevivência de empresas nascentes no estado de São Paulo: um estudo sobre capital humano, capital social e práticas gerenciais', Revista de Administração (RAUSP), Vol. 45, No. 4, pp.343-355, São Paulo.

Modigliani, F. and Miller, H.M. (1958) 'The cost of capital, corporate finance, and the theory of investment', American Economic Review, June, Vol. 48, No. 4, pp.261-297. 
Moreira, R.L., Encarnação, L.V., Bispo, O.N.A., Colauto, R.D. and Angotti, M. (2013) 'A importância da informação contábil no processo de tomada de decisão nas micro e pequenas empresas', Revista Contemporânea em Contabilidade, Vol. 10, No. 19, pp.119-140.

Motwani, J., Dandridge, T., Jiang, J. and Soderquist, K. (1999) 'Managing innovation in French small and medium-sized enterprises', Journal of Small Business Management, Vol. 37, No. 2, pp.106-114.

Mukhtar, S-M. (1998) 'Business characteristics of male and female small and medium enterprises in the UK: implications for gender-based entrepreneurialism and business competence development', British Journal of Management, Vol. 9, No. 1, pp.41-51.

Myers, S.C. (1984) 'The capital structure puzzle', Journal of Finance, July, Vol. 39, No. 3, pp.575-592.

Myers, S.C. and Majluf, N.S. (1984) 'Corporate financing and investment decisions when firms have information that investors do not have', Journal of Finance Economics, Vol. 13, No. 2, pp.187-221.

Neubauer, H., Mayr, S., Feldbauer-Durstmüller, B. and Duller, C. (2012) 'Management accounting systems and institutionalization in medium-sized and large family businesses: empirical evidence from Germany and Austria', European Journal of Management, Vol. 12, No. 2, pp.41-60.

Nogueira da Silva, A.M.J. and Braga, S.M.G. (2014) 'A importância do relacionamento bancário no financiamento das PME: Estudo numa agência bancária portuguesa', Revista Brasileira de Finanças, Vol. 12, No. 3, pp.291-317.

Paniccia, I. (1998) 'One, a hundred, thousands of industrial districts. Organizational variety in local networks of small and medium-sized enterprises', Organization Studies, Vol. 19, No. 4, pp.667-699.

Parisotto, I.R.S. and Rosa, R. (2005) 'A estrutura de capital da micro e pequena empresa de Blumenau', Revista Catarinense da Ciência Contábil do CRCSC, Vol. 4, No. 10, pp.71-88.

Ribeiro, H.C.M., Corrêa, R. and Souza, M.T.S. (2012) 'Perfil e evolução do tema pequenas e médias empresas em periódicos brasileiros: uma análise bibliométrica', Revista Gestão Organizacional, Vol. 5, No. 2, pp.242-258.

Romano, C.A., Tanewski, G.A. and Smymios, K.X. (2001) 'Capital structure decision making: a model for family business', Journal of Business Venturing, Vol. 16, No. 3, pp.285-288.

Ruengdet, K. and Wongsurawat, W. (2010) 'Characteristics of successful small and micro community enterprises in rural Thailand', Journal of Agricultural Education and Extension, Vol. 16, No. 4, pp.385-397.

Santos, V., Dorow, D.R. and Beuren, I.M. (2016) 'Práticas Gerenciais de Micro e Pequenas Empresas', Revista Ambiente Contábil, Vol. 8, No. 1, pp.153-186.

Serrasqueiro, Z. and Nunes, P.M. (2014) 'Financing behavior of Portuguese SMEs in hotel industry', International Journal of Hospitality Management, Vol. 43, pp.98-107.

Serviço Brasileiro de Apoio às Micro e Pequenas Empresas (SEBRAE) (2014) Anuário do Trabalho na Micro e Pequena Empresa [online] http://www.sebrae.com.br/Sebrae/ Portal\%20Sebrae/Anexos/Anuario-do\%20trabalho-na\%20micro-e-pequena\% 20empresa-2014.pdf (accessed 2 February 2016).

Silva Filho, L.A. (2014) Gestão de custos e formação de preço de venda, gestão de caixa e gestão de riscos: um estudo exploratório no arranjo produtivo local gesseiro, Dissertação (Mestrado em Ciências Contábeis) - Universidade Federal de Pernambuco, Recife.

Silva, J.A., Amboni, N., Ortigara, A.A. and Costa, A.M. (2014) 'DNA Empresarial: uma análise da gênese à operação das micro e pequenas empresas de Santa Catarina', Brazilian Business Review, Vol. 11, No. 2, pp.122-142.

Souza, A. and Clemente, A. (1998) 'Contextos, paradigmas e sistemas de custeio', Congresso Brasileiro De Gestão Estratégica De Custos, 1998 Anais, pp.141-156, ABC, Fortaleza. 
Souza, M.A., Lisboa, L.P. and Rocha, W. (2003) 'Práticas de Contabilidade Gerencial Adotadas por Subsidiárias Brasileiras de Empresas Multinacionais', Revista de Contabilidade \& Finanças - USP, No. 32, pp.40-57, São Paulo.

Spencer, X.S.Y., Joiner, T.A. and Salmon, S. (2009) 'Differentiation strategy, performance measurement systems and organizational performance: evidence from Australia', International Journal of Business, Vol. 14, No. 1, pp.83-103.

Stroeher, A.M. and Freitas, H. (2008) 'O uso das informações contábeis na tomada de decisão em pequenas empresas', Revista de Administração Eletrônica, Vol. 1, No. 1, pp.1-25.

Švárová, M. and Vrchota, J. (2013) 'Strategic management in micro, small and medium-sized businesses in relation to financial success of the enterprise', Acta Universitatis Agriculturae et Silviculturae Mendelianae Brunensis, Vol. 61, No. 7, pp.2859-2866.

Vilella, L.E. and Soares, L.C. (2009) 'Gestão Participativa, Informação e Acesso à Financiamentos no Banco do Brasil S/A, Na Percepção de Atores Locais e de Empresários de Micro e Pequenas Empresas Dos APLs De Cabo Frio - Rj e Nova Friburgo - Rj', Administraçaõ Pública e Gestão Social, Vol. 1, No. 3, pp.274-293.

Watson, R. (1994a) 'An empirical analysis of financial and non-financial manager's remuneration in small and medium-sized UK enterprises', Accounting \& Business Research, Vol. 24, No. 94, pp.176-188.

Watson, R. (1994b) 'The remuneration of non-owner managers in small and medium-sized UK enterprises', Journal of Management Studies, Vol. 31, No. 4, pp.553-568.

Watson, R., Storey, D., Wynarczyk, P., Keasey, K. and Short, H. (1996) 'The relationship between job specification and managerial remuneration in small and medium-sized enterprises: an empirical test of 'comparison income' and 'equity theory' hypotheses', Applied Economics, Vol. 28, No. 5, pp.567-576.

Wong, C., Marshall, J.N., Alderman, N. and Thwaites, A. (1997) 'Management training in small and medium-sized enterprises: methodological and conceptual issues', International Journal of Human Resource Management, Vol. 8, No. 1, pp.44-65. 